\title{
Korszerü, nagy szilárdságú autóipari acélok fejlesztése
}

\section{Development of Advanced High Strength Automotive Steels}

\author{
Tisza Miklós \\ Miskolci Egyetem, Gépészmérnöki Kar, Anyagszerkezettani és Anyagtechnológiai Intézet, Miskolc, \\ Magyarország, tisza.miklos@uni-miskolc.hu
}

\begin{abstract}
In recent decades, the automotive industry has faced ever-increasing demands. Increasing requirements can be observed in terms of both consumer expectations and legal requirements. On the consumer side, there is a demand for cars that are as economical as possible with lower fuel consumption, but providing also greater comfort and safety. These requirements are accompanied, from a legal point of view by more rigorous environmental regulations and requirements concerning the reduction of harmful emissions. Meeting these often-contradictory requirements is a growing challenge for car manufacturers and raw material suppliers, as well. Meeting the requirements in the most versatile way has resulted in tremendous progress over the last 40-50 years, both in the automotive industry and in the production and development of raw materials. The first part of this series of papers summarizes the main requirements in the automotive industry, as the main driving forces for material developments. Furthermore, the main types and properties of traditional highstrength steels, as well as the so-called first-generation Advanced High-Strength Steels will be introduced. In the second part, the main types and manufacturing processes of second generation advanced high-strength steels will be analyzed and some of the current steel developments will be presented through the results of the three generations of Advanced High-Strength Steels.
\end{abstract}

Keywords: Advanced High Strength Steels, AHSS, automotive industry applications.

\section{Összefoglalás}

Az utóbbi évtizedekben az autóipar folyamatosan növekvő követelményekkel nézett szembe. A növekvő követelmények mind a felhasználók, mind pedig a jogi előírások terén megfigyelhetők. Fogyasztói oldalról az egyre gazdaságosabb, kisebb fogyasztású, ugyanakkor magasabb kényelmi szintet és nagyobb biztonságot adó személygépkocsik iránti igény jelentkezik. Ezeket a követelményeket kiegészítik a fokozott környezetvédelmi előírások, amelyek minél kisebb károsanyag-kibocsátást tesznek lehetővé. Ezeknek a gyakran egymásnak is ellentmondó követelményeknek a kielégítése hatalmas kihívást jelent az autógyártókkal és az alapanyagot gyártókkal szemben. A követelmények kielégítésének igénye az elmúlt 40-50 évben hatalmas fejlődést eredményezett az autógyártóknál és az alapanyaggyártóknál is. Ebben a cikkben röviden áttekintjük az autóiparral szemben támasztott fő követelményeket, amelyek egyben az alapanyag-fejlesztés legfontosabb hajtóerőit is jelentik. A hagyományos nagy szilárdságú acélok mellett elsősorban a korszerű nagy szilárdságú acélok három generációjának ismertetésével foglalkozunk.

Kulcsszavak: nagy szilárdságú acél, autóipari alkalmazások.

\section{Bevezetés}

Az egyre fokozódó globális verseny miatt az autóiparban a gyártási költségek csökkentése kiemelt célkitűzés: ez több okból is szorosan kapcsolódik a járművek tömegének csökkentéséhez. A tömegcsökkentés a jármügyártásban nemzet- közi téren is a kutatási tevékenységek középpontjában áll. Ez számos tényezővel magyarázható, amelyek közül itt csak néhányat kiemelve: a szigorú károsanyag-kibocsátási előírások, az egyre fokozódó környezetvédelmi korlátozások, a minél gazdaságosabban üzemeltethető autókra vonat- 
kozó fogyasztói igények teljesítésében a járművek tömegcsökkentése meghatározó szerepet játszik. Egy autó teljes tömegét illetően az autó karosszériája döntő szerepet játszik. A karosszériaelemek - az ún. Body-in-White - gyártásában a lemezalakítás az egyik legfontosabb gyártási eljárás. Ez is indokolja, hogy a lemezalakításban is az új, innovatív, kis költségü gyártási folyamatok kidolgozása az egyik fő cél. A könnyü, kis tömegű gépjárműalkatrészek gyártásának két fő iránya a nagy szilárdságú acélok, illetve a könnyüfémek - hangsúlyozottan a különféle nagy szilárdságú alumíniumötvözetek - alkalmazása [1]. Jelen cikkben elsősorban a nagy szilárdságú acél alapanyagok fejlesztésével és e fejlesztések eredményeivel foglalkozunk. Ezt a hosszú, több évtizedes fejlesztési tevékenységet leginkább a korszerü nagy szilárdságú acélok fejlesztési eredményeivel jellemezhetjük, amely a nemzetközi szakirodalomban az AHSS - Advanced High Strength Steels fogalommal jelenik meg, így a továbbiakban gyakran mi is az AHSS általánosan elfogadott, rövid jelölést és megnevezést alkalmazzuk. Az ezen a területen végzett fejlesztések jól definiálhatóan három nagy csoportba sorolhatók, az ún. első, második és harmadik generációs, korszerü, nagy szilárdságú acélok csoportjába. E fejlesztések szorosan kapcsolódnak az autóiparral szemben támasztott követelményekhez is, amelyek az anyagfejlesztések hajtóerőit is jelentik.

\section{Az autóipari anyagfejlesztések haj- tóerői}

Az autóipari anyagfejlesztések fő hajtóerőit egyrészt a fogyasztók által támasztott elvárások (gazdaságosabb, biztonságosabb, nagyobb komfortfokozatú autók, minél jobb teljesítmény), kiegészülve a jogi előírásokkal (szigorodó környezetvédelmi előírások, minél kisebb károsanyag-kibocsátás, fokozott törésteszti előírások) jelentik. $\mathrm{E}$ két nagy csoport részben hasonló, részben egymásnak ellentmondó követelményeket jelent. A világszerte zajló globális verseny miatt az autóiparnak megfelelő válaszokat kell találnia ezekre a kihívásokra. Az elmúlt évtizedek fejlesztései egyértelműen rámutattak arra, hogy e sokrétű követelményrendszer kielégítésében a tömegcsökkentés kiemelt szerepet játszik. Figyelembe véve a különböző szerkezeti elemek arányát az autók össztömegében, megállapíthatjuk, hogy a karoszszériaelemek, a különféle alvázelemek és felfüggesztések, azaz a lemezalkatrészek tömegének csökkentése kulcsszerepet játszik. A lemezalkat- részek tömegének csökkentése a lemez $\neg$ vastagság csökkentését, és ezáltal a szilárdság növelését igényli. A szilárdság növelése viszont általában együtt jár az alakíthatóság csökkenésével, ami pedig alapvető technológiai problémákat vet fel. Az elmúlt évtizedek acélfejlesztései ezen ellentmondásos követelmények kiegyensúlyozását célozták, azaz olyan nagy szilárdságú acélok fejlesztését, amelyek alakíthatósági szempontból is megfelelnek az autóipar gyártásigényeinek.

\subsection{Az autóipari acélfejlesztések osztályo- zása}

Az utóbbi évtizedek acélfejlesztésében legáltalánosabban alkalmazott osztályozás - az ún. korszerü, nagy szilárdságú acélok, idegen kifejezéssel az Advanced High Strength Steels (AHSS) - szerinti csoportosításban ismertetjük az autóipari acélfejlesztéseket, amely szerint három fő csoportot különböztetünk meg, nevezetesen első, második és harmadik generációs nagy szilárdságú acélokat. Ezt az osztályozást szemlélteti grafikusan az 1. ábra.

Az 1. ábrán megfigyelhető a fémes anyagoknál jól ismert törvényszerüség is, mely szerint a szilárdság növekedésével az alakváltozó képesség hiperbolikus összefüggést követve csökken. Ezt szemléltetik azok a szakítószilárdság és a teljes nyúlás szorzatát mutató $\mathrm{R}_{\mathrm{m}} \times \mathrm{A}_{80}=\mathrm{C}$ (konstans) görbék, amelyek a korszerü nagy szilárdságú acélok osztályozásában további, fontos szerepet játszanak.

Az 1. ábrán feltüntettük az autóiparban évtizedeken át meghatározó szerepet betöltő lágyacélokat (IF, Mild), az ugyancsak jelentős autóipari alkalmazással bíró, hagyományos nagy szilárdságú acélokat (HS IF - High Strength Interstitial-Free, BH - Bake Hardenable, a CMn - Carbon Manganese, és ennek a csoportnak a fő képviselőjét jelentő HSLA, azaz High Strength Low-Alloyed acélokat) is.

A következő csoportot a korszerű nagy szilárdságú acélok első generációja jelenti (1G-AHSS). Ebbe a csoportba tartoznak a kettős fázisú DP-acélok, a fázisátalakulással indukált képlékenységet hasznosító TRIP-acélok, a komplex fázisú CP-acélok és a martenzites MS-acélok. Ezek az acélok az előzőkben bevezetett $\mathrm{R}_{\mathrm{m}} \times \mathrm{A}_{80}=\mathrm{C}$ görbéket tekintve $\mathrm{a}$ $\mathrm{C}=10000-25000$ tartományban helyezkednek el.

A korszerű, nagy szilárdságú acélok 2. generációját az $\mathrm{R}_{\mathrm{m}} \times \mathrm{A}_{80}=40000-65000$ tartományban található acélfejlesztések jelentik (2G-AHSS). Ennek a csoportnak a legjellegzetesebb képviselői az ikerképződés indukálta képlékenységgel jellem- 


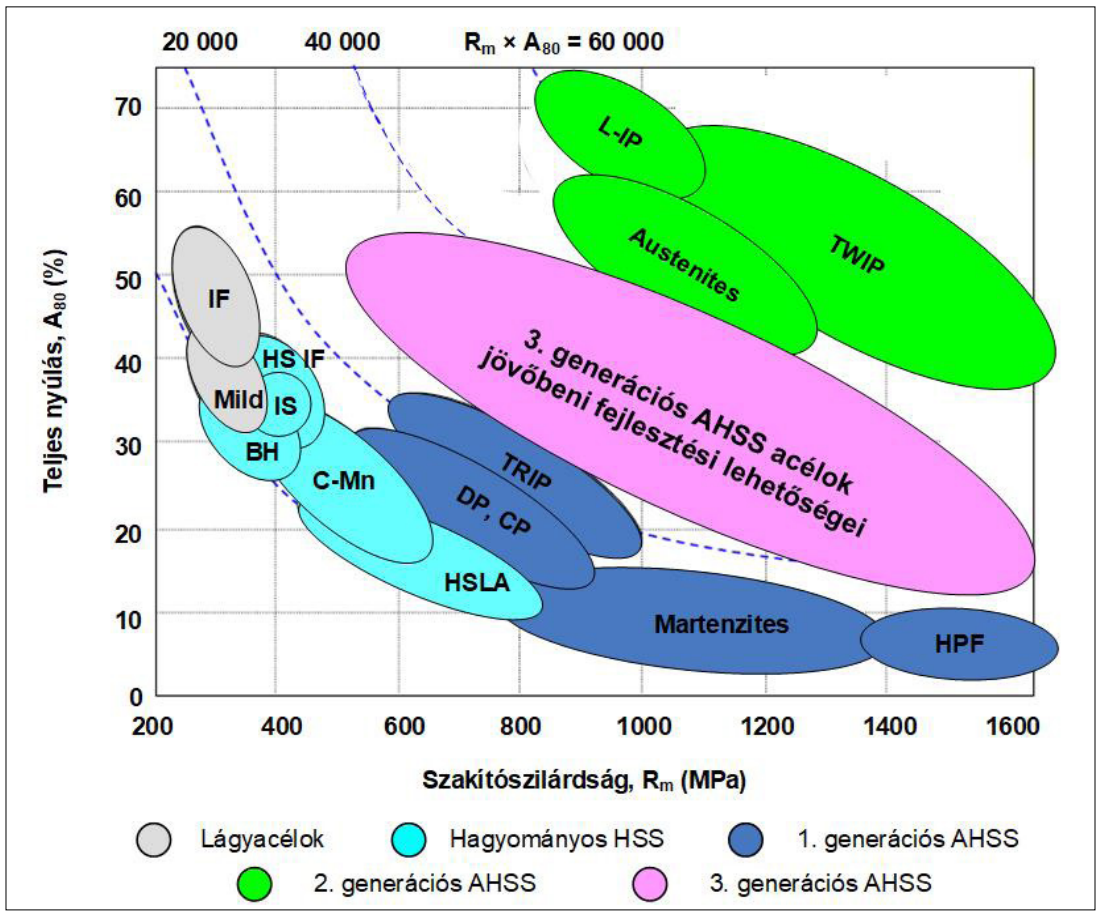

1. ábra. A szakítószilárdság $\left(R_{m}\right)$ és a fajlagos nyúlás $\left(A_{80}\right)$ kapcsolata az acélfejlesztések generációk szerinti osztályozásában [2]

zett Twinning Induced Plasticity (TWIP-) acélok, de idetartoznak a nagy Mn-tartalmú, korrózióálló AUST SS jelü, ausztenites acélok és az L-IP-acélok (teljes angol elnevezésük: Al-added Lightweight Steels with Induced Plasticity). Ezek az acélok a szilárdság és az alakíthatóság kiváló kombinációját biztosítják, ugyanakkor ez a csoport a kiváló tulajdonságai ellenére sem ért el igazi áttörést az autóipari alkalmazásban, elsősorban a kis gyártási termelékenység és a nagy gyártási költségek miatt.

A korszerű nagy szilárdságú acélok (AHSS) következő fejlesztési szakasza vezetett a 3. generációs nagy szilárdságú acélok (3G-AHSS) kifejlesztéséhez, amely még napjainkban is a fejlesztés és az első ipari megvalósítás szakaszában van, azonban az acélgyártók már számos figyelemre méltó eredményt értek el ezen a területen.

$\mathrm{Az}$ alapvető gondolat e fejlesztések mögött $\mathrm{az}$ 1. és 2. generációs nagy szilárdságú acélok közötti tartományba eső tulajdonságok biztosítása, amelyeket a szakítószilárdság és az alakíthatóság kapcsolatát mutató 1. ábra alapján értelmezhetünk. E csoport kidolgozásánál kiemelt fontosságú, hogy a tervezett, kiváló mechanikai tulajdonságokat kevesebb ötvözővel és így olcsóbban valósítsák meg, különösen a 2. generációs acélokhoz viszonyítva. Ezen acélok mikroszerkezete jellemzően több fázisból (például nano-/ultrafinomszemcsés ferritből, martenzitből vagy bainitből) áll, és egy további fázissal (például ausztenit) kombinálva, fokozott alakíthatóságot és nagyobb alakváltozási keményedést biztosítanak. Ezzel a fejlesztési koncepcióval a GPa tartományba eső nagy szilárdságú acélok állíthatók elő, egyidejüleg figyelemre méltó alakíthatósággal [3].

A következőkben e három generáció néhány képviselőjének bemutatásán keresztül elemezzük a közelmúlt főbb acélfejlesztési törekvéseit és eredményeit.

\section{A korszerü, nagy szilárdságú acélok típusai}

A korszerű, nagy szilárdságú (AHSS) acélok különböző generációinak legfontosabb jellemzői, hogy komplex, gondosan meghatározott kémiai összetételű és többfázisú mikroszerkezetük van, amely pontosan szabályozott hevítési és hütési folyamatok eredményeként állítható elő. Különböző szilárdságnövelési mechanizmusokat alkalmaznak a jelentősen megnövelt szilárdság, a jobb alakíthatóság, a fokozott szívóssági és kifáradási tulajdonságok elérése érdekében, hogy amennyire csak lehetséges, megfeleljenek az autók szerkezeti elemeire előírt, összetett követelményeknek. 


\subsection{Első generációs nagy szilárdságú acélok}

Ennek a csoportnak a legjellegzetesebb és legszélesebb körben alkalmazott típusai a DP- és a TRIP-acélok, de ebben a csoportban feltétlenül érdemes megemlíteni az utóbbi időben egyre növekvő autóipari alkalmazással rendelkező, kimondottan a meleg lemezalakítás céljára kifejlesztett martenzites acélokat is. Ezeket az acélokat Press Hardening Steels (PHS) megnevezéssel illeti a nemzetközi szakirodalom. Kiváló tulajdonságaik hasznosítására speciális, kimondottan ezen acéltípus feldolgozására szolgáló új technológiai eljárásokat fejlesztettek ki.

\subsubsection{Kettős fázisú, DP-acélok}

A kétfázisú (DP = Dual Phase) acélok az első generációs nagy szilárdságú acélok fejlesztésében és az autóipari alkalmazásokban egyaránt fontos szerepet töltenek be. A DP-acélok a kettős fázisú acélokkal kapcsolatos korai kutatások alapján fejlődtek ki az 1970-es évek végén és az 1980-as évek elején. Széles körü felhasználásuk elsősorban annak köszönhető, hogy kedvező szilárdsági és alakíthatósági paramétereik a hagyományos nagy szilárdságú - például a HSLA - acélokkal összehasonlítva lényegesen kedvezőbb tulajdonságkombinációt eredményeznek. A DP-acéloknak nagy a fajlagos szilárdsága, jó a kezdeti alakváltozási keményedése és kiváló az alakváltozó képessége. Ezek a tulajdonságok teszik különösen alkalmassá járművek karosszériaelemeinek, különféle záróelemeknek, üzemanyagtartályoknak alakítással való gyártására [4].

A 2. ábra a DP-acélok különféle gyártási lehetőségeinek (A-, B- és C-eljárás) hőmérséklet-idő diagramjait szemlélteti. Mindegyik eljárásnál kiemelt jelentősége van az ún. interkritikus hőmérsékletnek.

A kettős fázisú (DP) acélok főleg ferrit mátrixba ágyazott, kemény martenzit-, egyes esetekben

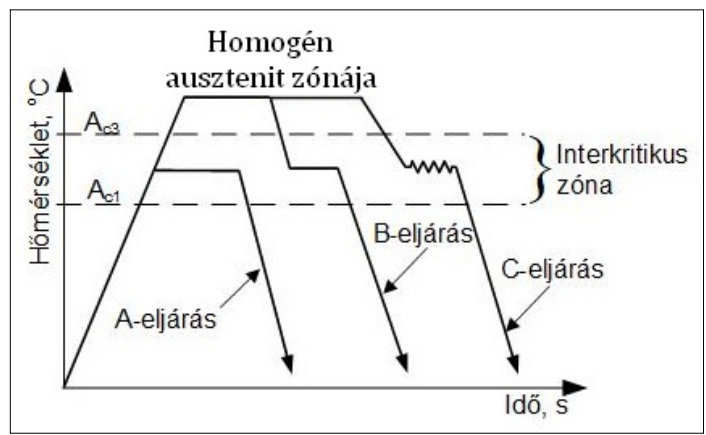

2. ábra. DP-acélok különböző gyártási lehetőségeinek idő-hőmérséklet diagramja bainit- szigeteket tartalmaznak második fázisként. Jellemző, hogy a folyamatos, összefüggő ferritszemcsék kiváló alakíthatóságot biztosítanak. Az alakítás során az alakváltozás a martenzites szigeteket körülvevő, kis szilárdságú ferrit fázisra koncentrálódik; a kiváló alakíthatóság mellett ez a mikroszerkezeti sajátosság az alapja a DP-acéloknál tapasztalt jelentős alakváltozási keményedésnek is [5].

\subsubsection{TRIP-acélok}

A fázisátalakulással indukált képlékenységet hasznosító acélok, amelyek megnevezésére a szakirodalomban az angol megnevezés szavainak kezdőbetűiből alkotott TRIP-acélok elnevezés honosodott meg. Ezek az acélok is kiválóan alkalmasak a tömegcsökkentést előtérbe helyező karosszériaelemek és -szerkezetek gyártására, egyúttal további előnyöket eredményeznek a biztonság növelésében is. A TRIP-acélok egyik fő jellemzője, hogy a mikroszerkezetben jelen lévő maradék ausztenit alakváltozás vagy feszültség hatására bekövetkező átalakulása jelentős szilárdságnövekedést eredményez, miközben a gyártási eljárástól függően viszonylag jelentős az alakíthatóságuk is.

A TRIP-acélok mikroszerkezete ferrit mátrixba beágyazódó martenzit, bainit és maradék ausztenit szövetelemeket tartalmaz. Kiváló alakíthatóságuk és nagy szilárdságuk a maradék ausztenit alakváltozás hatására bekövetkező martenzitté alakulásával magyarázható, amely kiváló szilárdság és alakváltozás kombinációt, valamint a dinamikus hatásokkal szemben is jó ellenálló képességet eredményez.

A TRIP-acélok tipikus gyártási eljárása a következő: az acélt az ausztenit zónába hevítik, és a homogén ausztenites állapot eléréséhez szükséges ideig hőn tartják. Ezt követi az interkritikus hőmérsékletre hűtés, majd ezen a hőmérsékleten végrehajtott melegalakítás. A következő lépést a bainit zónába történő gyors hütés és a bainites tartományban végzett hőntartás jelenti.

A TRIP-acélokat viszonylag kis ötvözőtartalom jellemzi. Például a TRIP 790 acélban $\left(\mathrm{R}_{\mathrm{m}} \approx 790 \mathrm{MPa}\right)$ az ötvözőelemek teljes mennyisége körülbelül 3,5 tömegszázalék. A megfelelő ötvözőelemek kiválasztása és a kívánt tulajdonságok eléréséhez szükséges mennyiség kritikus az ötvözet tervezett mechanikai tulajdonságait illetően. A TRIP-acélok általában nagyobb karbontartalmúak, mint a DP-acélok [7]. 


\subsubsection{Melegalakításra kifejlesztett PHS-acélok}

A korszerű, nagy szilárdságú acélok között a melegalakítással és az alakítószerszámban végzett edzéssel megvalósított technológia alkalmazása a korszerű, nagy szilárdságú acélok (Press Hardening Steel - PHS) egészen különleges, egyedülálló csoportját képezi: ezek többnyire különféle, bórötvözésű mangánacélok, és széles körben alkalmazhatók nagy szilárdságú szerkezeti elemek gyártására (pl. személyautók A és B oszlopainak gyártásában). Több típusuk ismert, közülük a 22MnB5 ötvözetet tekintik a PHS-acélok alaptípusának. A melegalakítás + edzés szerszámban eljárás tipikus idő-hőmérséklet diagramja látható a 3. ábrán.

A hevítés, hőntartás, alakítás és gyors hütés 3. ábrán bemutatott eljárás megfelelő kombinációjával kiváló szilárdsági tulajdonságokkal rendelkező, összetett alkatrészek állíthatók elő [8]. Az eljárásnak különböző technológiai változatai léteznek, köztük az úgynevezett közvetlen és közvetett melegalakítás.

E két alapvető eljárás mellett további eljárásváltozatok is vannak: a végső mikroszerkezet és az alkatrész mechanikai tulajdonságai nagyon hatékonyan kézben tarthatók, szabályozhatók a hőntartási hőmérséklettől és a szabályozott hűtési folyamattól függően. A hőntartási hőmérséklettől függően két további eljárásváltozat származtatható: a teljes ausztenitesítés tekinthető az alapve- tő változatnak, azaz amikor a hőntartási hőmérsékletet a homogén $\gamma$-zónában választják meg. A hőntartási hőmérséklettől függően egy további eljárásváltozat képezhető, ha a hőntartási hőmérsékletet az $(\alpha+\gamma)$ kritikus tartományban (azaz az $A_{1}$ és az $A_{3}$ hőmérséklet között) választják. Ez azt jelenti, hogy nincs teljes ausztenitesítés; a kiindulási mikroszerkezet ezen a hőntartási hőmérsékleten ferritet és ausztenitet tartalmaz, mégpedig a tényleges hőntartási hőmérsékletnek az $\mathrm{A}_{1}$ és $\mathrm{A}_{3}$ kritikus hőmérsékletek közötti helyzetétől függő mennyiségben. Ebben az esetben csak az ausztenittartalom alakulhat martenzitté, és a végső mikroszerkezet az alakítás és a gyors hűtés után bizonyos mennyiségü ferritet is tartalmaz. Nyilvánvalóan ez a változat kisebb szilárdságot eredményez a teljes ausztenitesítéshez viszonyítva, ugyanakkor kedvezőbb alakíthatóságot és jobb szívóssági jellemzőket is biztosít.

További eljárásváltozatok származtathatók a hűtési sebesség alakítás utáni változtatásával is. Ha a hűtési sebesség kisebb a felső kritikus értéknél, akkor a végső mikroszerkezet a martenzit mellett bainitet is tartalmaz. Ez a bainit mennyiségétől függően kisebb szilárdságot eredményez, de a megnövekedett szívóssággal együtt előnyös lehet a bainit jobb energiaelnyelési tulajdonságai miatt olyan alkatrészeknél, amelyeknél az ütközésállóság, a törés elleni biztonság kiemelt szerepet játszik, növelve az alkatrész törésállóságát.

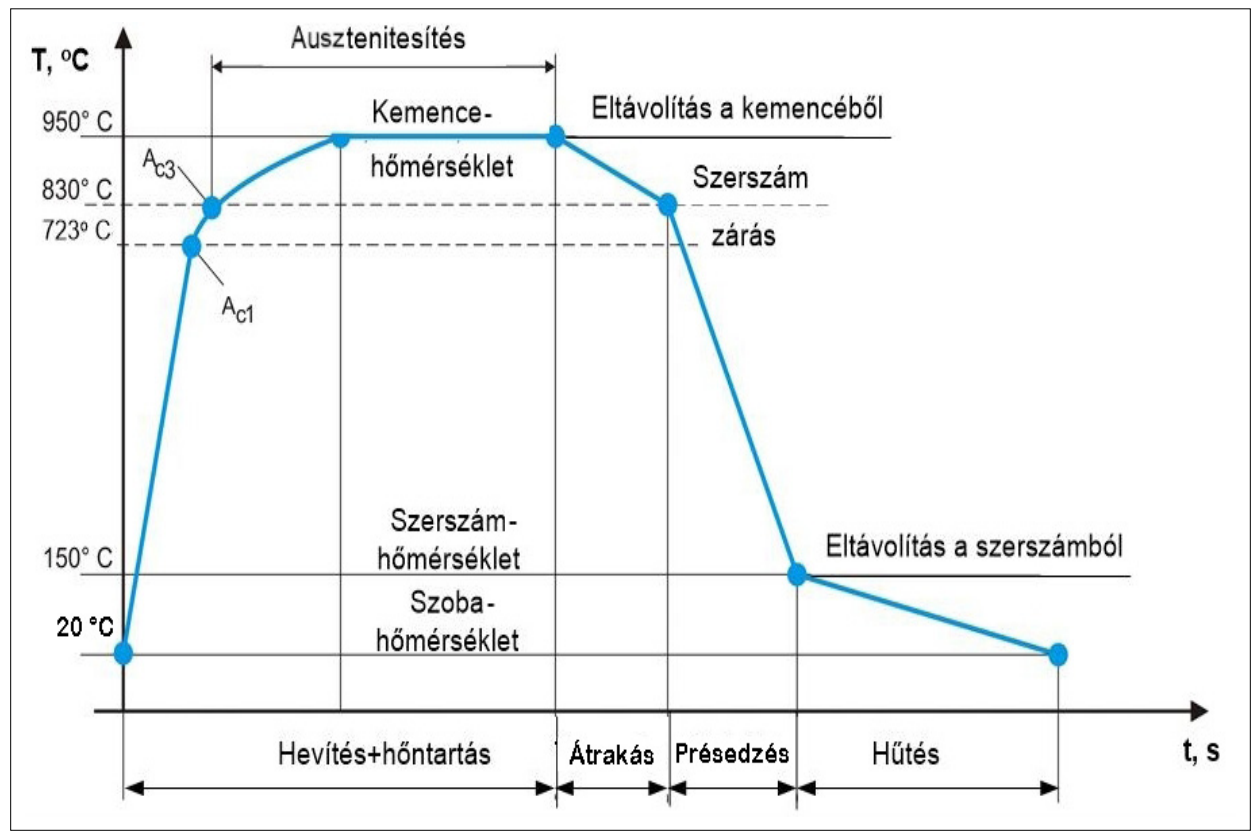

3. ábra. A melegsajtolás + szerszámban edzés (Hot Press Forming) eljárás hőmérséklet-idő diagramja 
Fontos, hogy az alakítás az $\mathrm{M}_{\mathrm{s}}$ (a martenzites átalakulás kezdeti hőmérséklete) fölött befejeződjön: ezek az anyagminőségek ebben a szakaszban még megfelelő alakíthatósággal rendelkeznek. Az alakítás után az alakított alkatrészt a szerszámmal együtt lehűtik: ennek a hűtésnek biztosítania kell a kritikus hűtési sebességet, hogy az elvárt mennyiségben martenzites mikroszerkezetet kapjunk. Ezzel a folyamattal csökkenthető az alakítás utáni visszarugózás, és így kiváló szilárdsági tulajdonsággal rendelkező alkatrészek alakíthatók komplex geometriákká.

A tipikus melegen sajtolt, edzhető acélok (PHSacélok) szakítószilárdsága az $\mathrm{R}_{\mathrm{m}}=1500-2000 \mathrm{MPa}$ értéket is eléri. Az elmúlt évtizedekben széles körben alkalmazták ezeket az eljárásváltozatokat különféle biztonsági és ütközésálló karosszériaelemekben. Az új generációs PHS-acélok még a $2000 \mathrm{MPa}$ feletti szilárdságot is elérik. Ezeket a PHS-acélokat és az előzőkben elemzett eljárásváltozatokat elsősorban olyan elemek gyártásánál alkalmazzák, ahol a fokozott törésbiztonság mellett, jellemzően csak kis alakváltozás megengedett (például az A és B oszlop megerősítései, különféle küszöbelemek, padlólemezek).

\subsection{Második generációs nagy szilárdságú acélok}

A korszerű nagy szilárdságú acélok 2. generációját az $\mathrm{R}_{\mathrm{m}} \times \mathrm{A}_{80}=40000-65000$ tartományban található acélfejlesztések jelentik (2G-AHSS). Ennek a csoportnak a legjellegzetesebb képviselői az ikerképződés indukálta képlékenységgel jellemzett TWIP-acélok, de idetartoznak egyes nagy Mn-tartalmú, korrózióálló ausztenites acélok (például az AUST SS) és a Lightweight Induced Plasticity névvel illetett L-IP-acélok is. Ezek az acélok a szilárdság és az alakíthatóság kiváló kombinációját biztosítják, ugyanakkor ez a csoport egyelőre a kiváló tulajdonságai ellenére sem ért el igazi áttörést az autóipari alkalmazásban, elsősorban a kis gyártási termelékenység és a nagy gyártási költségek miatt.

\subsubsection{TWIP-acélok}

A TWIP-acélok azon a különleges mechanizmuson alapulnak, amelynek révén az alakítási ikerképződési mechanizmus hasznosításával kiemelkedő egyensúlyt lehet elérni a szilárdsági és az alakváltozási, alakíthatósági jellemzők között. Az acélcsoport megnevezése is ebből a jellegzetes alakváltozási módból, azaz az ikerképződés indukálta képlékenység angol megnevezésének mozaikszavából (TWIP) származik. Az ikerképződés az n keményedési kitevő értékének jelentős növekedését eredményezi, az ikerképződési mechanizmus kapcsán egyre finomabb mikroszerkezet révén.

A TWIP-acélok jellemzően nagy mangántartalmúak (Mn = 17-24\%), aminek következtében az acél szobahőmérsékleten is teljesen ausztenites. Ezek az acélok kiemelkedő szilárdság-alakíthatóság kombinációval jellemezhetők (például $\mathrm{R}_{\mathrm{m}}>1000 \mathrm{MPa}$ feletti szakítószilárdság esetén is akár 50-60 \%-ot meghaladó teljes nyúlás érhető el), azaz a TWIP-acélok a rendkívül nagy szilárdság mellett ugyancsak rendkívül nagy alakíthatóságot mutatnak [9].

A TWIP-acélok további jellemzője a nagy keményedési kitevő, amely $\mathrm{n} \geq 0,4$ értéket is elérhet. A TWIP-acéloknál az alakváltozási keményedés stabilitása szorosan összefügg a rétegződési hiba energiájával (Stacking Fault Energy - SFE). Ez a paraméter határozza meg alapvetően a TWIP-acélok alakváltozási viselkedését.

Az előzőkben vázolt jellemzők a szilárdság és az alakváltozó képesség egészen kivételes kombinációját eredményezik, amely az 1 . ábrán vázolt $\mathrm{R}_{\mathrm{m}} \times \mathrm{A}_{80}=$ állandó értékének a $\mathrm{C}=40000-65000$ tartományban jelöli ki a helyét. A TWIP-acélok e kiemelkedő mechanikai jellemzőik ellenére sem értek el átütő alkalmazási sikereket az autóiparban, elsősorban a kis termelékenység és a nagy költségek miatt.

\subsubsection{Ausztenites korrózióálló acélok (AUST SS)}

Az ausztenites korrózióálló acélok kiváló tulajdonságai jól ismertek, és számos területen nyernek alkalmazást. Autóipari alkalmazásuk a 2. generációs nagy szilárdságú acélok fejlesztése során került a kutatások előterébe.

Az ausztenites korrózióálló acélok jellemzően nagy króm- és nikkeltartalmúak. Legjellemzőbb képviselőjük a 18\% Cr- és 8\% Ni-tartalmú, klasszikus 18/8-as korrózióálló acél, amely kiváló korrózióállósága mellett az ugyancsak kiváló mechanikai tulajdonságairól ismert. Ebből a szempontból különösen a jelentős, hidegalakítási keményedési képességük figyelemre méltó. Ezek az acélok kis folyáshatárral, jelentős képlékenységgel, nagy szakítószilárdsággal és kiváló szívóssági tulajdonságokkal jellemezhetők az ausztenites lágyítás utáni állapotban.

Az ilyen acélok kiváló alakíthatósági jellemzőiket a felületen középpontos köbös kristályrendszerből következő 12 csúszási rendszernek köszönhetik. Emellett az interstíciós elemek minimális mennyiségét is meg kell említenünk, mivel ez is hozzájárul az akadálymentes diszlokációs 
csúszási mechanizmus müködéséhez, és ezáltal a kiváló képlékenységi jellemzőkhöz.

Az AUST SS acélokat jellemzően folyamatos szalagöntéssel és meleghengerléssel állítják elő. Az így előállított lemezeket hidegen hengerlik a kívánt vastagság eléréséig, majd az ennek során bekövetkező felkeményedést hidrogén vagy nitrogén védőatmoszférában lágyítják. Az újrakristályosodás során megfelelő termikus programmal biztosítják a kellően finom szemcseszerkezetet és az esetleges karbidkiválások oldódását. Az oldó izzítás után a hütést kellő gyorsasággal kell elvégezni a karbidok kiválásának elkerülése érdekében.

\subsubsection{Alumíniumötvözésü, fokozott képlé- kenységü acélok (L-IP-acélok)}

A tömegcsökkentés indukálta acélfejlesztések különleges típusai az L-IP-acélok, amelyeknek a neve is erre utal (L-IP - Lightweight Induced Plasticity). Ezt a megnevezést elsősorban a Fe-Mn-Al-C ötvözettípusnál alkalmazzák, amelyeknél külön jellegzetesség az Al-ötvözés: az Al a kulcsötvöző a tömegcsökkentés biztosításában [10].

Az ötvözőelemeket tekintve, a Mn és a C ausztenitképző, az Al pedig ferritstabilizáló, továbbá fokozza a $\mathrm{C}$ metastabilis oldódását a diffúzióképesség csökkentése révén. Az L-IP-acélok megfelelő vegyi összetétel esetén ún. triplex mikroszerkezetet eredményeznek, amely ausztenitet, ferritet és к-karbidokat - (Fe,Mn) ${ }_{3} \mathrm{AlC}$ - tartalmaz.

\subsection{Harmadik generációs nagy szilárdságú acélok}

A 3. generációs nagy szilárdságú acélok (3G-AHSS) kifejlesztésének fő célja az 1. és 2. generációs AHSS-acélok tulajdonságai közötti tartományba eső mechanikai tulajdonságkombinációk elérése kisebb ötvözőmennyiséggel, következésképpen gazdaságosabb, kisebb költségű gyártással, amelyek széles körü alkalmazása rövid időn belül megvalósítható. Ebből a csoportból a közelmúlt néhány fejlesztési eredményét mutatjuk be.

\subsubsection{Edzett és particionált Q\&P-acélok}

A gyors hütéssel (edzéssel) és particionálással gyártott acélok a harmadik generációs AHSSacélok legújabb fejlesztéseinek eredményei. A Q\&P-acélok jellemzően karbon-, mangán-, szilícium-, nikkel- és molibdénötvözőket tartalmaznak. A szilárdsági elvárásoktól függően 4\% körüli ötvözőt tartalmaznak, ami jóval kevesebb, mint a második generációs AHSS-acéloknál, így előállításuk kevésbé költséges gyártási eljárásnak tekinthető [11].

A Q\&P-acél hőkezelése közben a gyors hütést megszakítják, és az acélt újra felhevítik a partici- onáláshoz. Ez 5-12\% stabil maradék ausztenitet, 20-40\% ferritet és 50-80\% martenzitet eredményez. A Q\&P eljárás akár 2100 MPa feletti szakítószilárdságú acélokat is eredményezhet, 9\% egyenletes nyúlással és körülbelül 13\% teljes nyúlással. Ennek az acélnak az alakváltozási viselkedése összevethető a DP980 acéléval, amely hidegen alakíthatónak tekinthető.

A Q\&P-acélok a C-Si-Mn, C-Si-Mn-Al vagy más hasonló összetételek sorozatát képezik, amelyeket a gyors hűtés és particionálás (Q\&P, ahol a particionálás az ötvözőelemeknek az egyes fázisok közötti tudatos megosztását jelenti) hőkezelési eljárással állítanak elő. A Q\&P-acélok mikroszerkezete ferrit (részleges ausztenitesítés esetén), martenzit és maradék ausztenit, amely kitűnő szilárdsági és alakváltozási jellemzőket eredményez. Ezek a tulajdonságok teszik lehetővé a felhasználásukat gépjárműalkatrészekként való alkalmazásra. A Q\&P-acélok alkalmasak viszonylag bonyolult alakú gépjárműelemek hidegalakítással való előállítására, mindezt az üzemanyag-takarékosság és az utasbiztonság növelése mellett.

A Q\&P-eljárásnak két alapvető változatát dolgozták ki. Az alapváltozat egy gyors hütést (Quenching), majd azt követő particionálást (Partitioning = ötvözőmegosztás, főleg a karbon vonatkozásában) tartalmaz. Az újabb változat egy ún. kettős stabilizációs hőciklust (Double-Stabilization Thermal Cycle - DSTC) alkalmaz [12].

Az újabb eljárás, a kettős stabilizációs hőciklus célja nagy térfogatarányú maradék ausztenit és martenzit biztosítása kellő karbontartalommal a nagy szilárdság biztosítása érdekében. Hasonlóan az előzőkben elemzett alapváltozathoz, ugyancsak cél a karbidképződés megakadályozása annak érdekében, hogy minél több karbon diffundáljon a martenzitből az ausztenitbe a particionálási folyamat során. Ennek az eljárásnak a hőmérséklet-idő ciklusa látható a 4. ábrán.

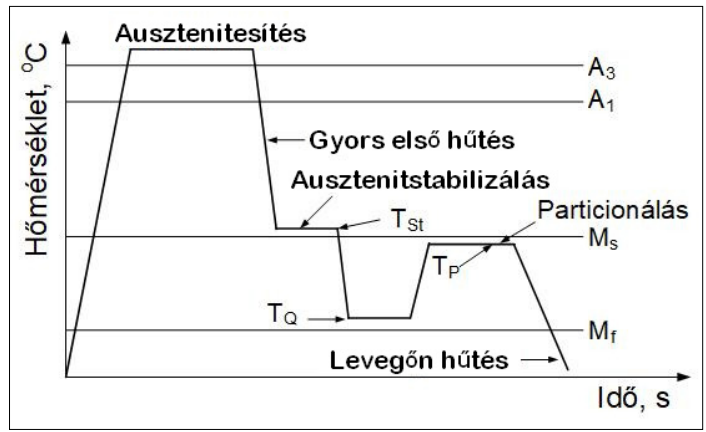

4. ábra. $A Q \& P$ eljárás hőmérséklet-idő diagramja (DSTC) 
A kettős stabilizációs termikus ciklussal (DSTC) gyártott Q\&P-acélok gyártási lépései az alábbiakban összegezhetők:

1. Ausztenitesítés. A kettős stabilizációs hőciklus első lépése egy teljes körű ausztenitesítés.

2. Kezdeti gyorshütés. Az ausztenitesítést egy kellően gyors, első hűtés követi, amelynek a célja az esetleges bainites átalakulás megakadályozása. Ezt a hűtést közvetlenül a martenzites átalakulás kezdeti $\left(\mathrm{M}_{\mathrm{s}}\right)$ hőmérséklete fölötti értékig folytatjuk. Ezen a hőmérsékleten az ausztenit elsődleges stabilizálása történik.

3. Második gyorshütés. A kezdeti gyorshütést az $\mathrm{M}_{\mathrm{f}}$ hőmérséklet feletti hőmérsékletig végzett gyorshűtés követi, amelyen a hőntartással az ausztenit/martenzit arány beállítása történik.

4. Karbon-particionálás. A particionálást az $\mathrm{M}_{\mathrm{s}}$ hőmérséklet alatt végezzük: ennek egy másodlagos stabilizálás a célja, amelynek során a martenzitből karbon diffundál az ausztenitbe, növelve az ausztenit karbontartalmát, ezáltal annak stabilitását is. Ennek köszönhetően tovább növekszik az ausztenit martenzitté való átalakulással szembeni ellenálló képessége.

5. Levegőn hütés. Erről a hőmérsékletről szobahőmérsékletig levegőn hütjük a mintegy $30 \%$ ausztenitet, $23 \%$ ferritet és $47 \%$ martenzitet tartalmazó acélt. A karbidképződés megakadályozására további, Si és Al ötvözőket is adagolnak.

\subsubsection{A TRIP-hatást hasznosító bainites-ferri- tes acélok}

A harmadik generációs nagy szilárdságú acélok a TRIP-hatást hasznosító, gyengén ötvözött bainit-ferrites (TBF) acélok egy további figyelemre méltó fejlesztését jelentik. A különböző szakirodalmak a TRIP-hatást hasznosító TBF-acélokként, egyes irodalmak $\delta$-TRIP-acélként hivatkozzák, az alumíniumtartalom miatt kialakuló, kisebb sűrűségre utalva.

A TBF-acélok mikroszerkezete bainit+ferrit mátrixból áll, maradék ausztenitrészecskékkel. A TBF-acélok tipikus kémiai összetétele $C$, Si és Mn fő ötvözőelemeket tartalmaz. További szokásos ötvözők az Al, Nb és Cr különböző összetétel-kombinációkban [13]. A Si gátolja a karbid képződését a bainites fázisátalakulás során, ami növeli a maradék ausztenit C-tartalmát, és ezáltal lehetővé teszi a maradék ausztenit karbonnal való stabilizálását.

Ezen acélok egyik nagy előnye a Q\&P-acélokhoz képest, hogy hagyományos hőkezelő létesítményekben előállíthatók, míg a Q\&P-acélok gyártá- sához a hőkezelő létesítményeket jelentősen át kellett alakítani. Előállításuk a teljesen ausztenites mikroszerkezetből, gyors hütést követően a bainit tartományban végzett izotermikus hőntartással történik.

\subsubsection{Nanoszerkezetű acélok}

A harmadik generációs, korszerü, nagy szilárdságú acélok egy további csoportja, az ún. Nano-acél ${ }^{\circ}$, amely még többnyire a fejlesztés stádiumában van, kereskedelmi forgalomban nem elérhető. Ennek a típusnak a jellegzetessége a speciális kémiai összetétellel és hőkezeléssel létrehozott nanokristályos szerkezet. Öntés után az acél elsősorban ausztenites szövetszerkezetü, némi boriddal. Hőkezelés után az ausztenitet nanométeres méretűre finomítják. Képlékeny alakváltozás során a nanoméretű fázisok feszültségindukálta képződése növeli az alakváltozási keményedési képességet [14].

\section{Következtetések}

Az autóipar az elmúlt évtizedekben egyre növekvő követelményekkel néz szembe. A növekvő követelmények mind a felhasználók, mind pedig a jogi előírások terén megfigyelhetők. Fogyasztói oldalról az egyre gazdaságosabb, kisebb fogyasztású, ugyanakkor magasabb kényelmi szintet és nagyobb biztonságot adó személygépkocsik iránti igény jelentkezik, amelyeket jogi oldalról a fokozott környezetvédelmi előírások egészítenek ki, amelyek minél kisebb károsanyag-kibocsátás elérését célozzák. E követelmények kielégítésében az autóiparban a tömegcsökkentés kiemelt szerepet tölt be. A tömegcsökkentési igények egyre nagyobb szilárdságú lemezalapanyagok alkalmazását teszik szükségessé.

A nagy szilárdságú acélok fejlesztése a tömegcsökkentési igények szempontjából kiemelt jelentőségű. Az elmúlt évtizedekben a nagy szilárdságú acélok fejlesztésének három generációja - első, második és harmadik generációs, korszerü nagy szilárdságú acélok fejlesztése figyelhető meg. Ebben a cikkben ezen acélfejlesztések három generációját tekintjük át, az egyes generációk legfontosabb képviselőinek bemutatásával, elemezve az egyes nagy szilárdságú acélok legfontosabb jellemzőit, gyártási eljárásaikat és az autóipari alkalmazási területeiket.

E fejlesztések közül egyes típusok (pl. a DP- és a TRIP-acélok) már széles körben alkalmazottak az autógyártásban, míg más típusok (elsősorban a második generációs fejlesztések, mint például a 
TWIP-acélok) a kisebb gyártási termelékenység és nagyobb gyártási költségek miatt még nem nyertek széles körű alkalmazást.

A fejlesztések legújabb, ígéretes szakasza a harmadik generációs nagy szilárdságú acélok fejlesztése, amelynek célja az első és a második generációs fejlesztések közötti rés áthidalása. E csoport kidolgozásánál kiemelt fontosságú, hogy a tervezett kiváló mechanikai tulajdonságokat kevesebb ötvözővel és így olcsóbban valósítsák meg, különösen a 2. generációs acélokhoz viszonyítva.

\section{Köszönetnyilvánítás}

A cikkben ismertetett kutatómunka az „AutoTech A képlékenyalakítás, hegesztés és hőkezelés fejlesztése a magyar autóiparban” (Nyilv. tart. sz.: TÁMOP4.2.2/A-11/1-KONV-2012-0029), valamint a Horizont 2020 „Low Cost Materials Processing Technologies for Mass Production of Lightweight Vehicles - LoCoMaTech" (EU Grant No: H2020-NMBP-723517GV-2016)" című projektekben elért eredményeket összegezte. A kutatómunkában résztvevők mindkét projekt támogatását ezúton is köszönik.

\section{Szakirodalmi hivatkozások}

[1] Tisza M.: Képlékenyalakítás az autóiparban. Miskolci Egyetemi Kiadó, 2015. 294.

[2] Tisza M.: Development of Lightweight Steels for Automotive Applications. In: Ashutosh Sharma (ed.): Engineering Steels and High Entropy-Alloys. IntechOpen, 2020 https://doi.org /10.5772/ intechopen.91024

[3] Nanda T., Singh V., Singh V., Chakraborty A., Sharma S.: Third generation of advanced high-strength steels: Processing routes and properties. Journal of Materials: Design and Applications, 233/2. (2019) 209-238. https://doi.org/10.1177/1464420716664198

[4] Li C., Li Z., Cen Y., Ma B., Huo G: Microstructure and mechanical properties of dual phase strip steel in the over-aging process of continuous annealing. Materials Science and Engineering: A, 627 (2015) 281-289. https://doi.org/10.1016/j.msea.2014.12.109

[5] Meng Q., Li J., Wang J., Zhang Z., Zhang L.: Effect of water quenching process on microstructure and tensile properties of alloy cold rolled dual-phase steel. Materials \& Design, 30/7. (2009) 2379-2385. https://doi.org/10.1016/j.matdes.2008.10.026

[6] Rana R., Liu C., Ray R. K.: Evolution of microstructure and mechanical properties during thermo-mechanical processing of a low-density multiphase steel for automotive application. Acta Materialia, 75 (2014) 227-245. https://doi.org/10.1016/j.actamat.2014.04.031

[7] Kuziak R., Kawalla R., Waengler S.: Advanced high strength steels for automotive industry: Archives of Civil and Mechanical Engineering, 8/2. (2008) 103-117. https://doi.org/10.1016/S1644-9665(12)60197-6

[8] Tisza M.: Hot forming of boron alloyed Manganese steels. Materials Science Forum, 885 (2015) 25-30. https://doi.org/10.4028/www.scientific.net/ MSF.885.25

[9] Chung K., Ahn K., Yoo D. H., Chung K. H., Seo M. H., Park S. H.: Formability of TWIP (twinning induced plasticity) automotive sheets. International Journal of Plasticity, 27/1. (2011) 52-81. https://doi.org/10.1016/j.ijplas.2010.03.006

[10] Scott C., Remy B., Collet J. L. et al: Precipitation strengthening in high manganese austenitic TWIP steels. International Journal of Materials Research, 102/5. (2011) 538-549. https://doi.org/10.3139/146.110508

[11] Wang, J., Yang, Q. et al.: A phenomenon of strain induced bainitic transformation and its effect on strength enhancement in a lightweight transformation-induced-plasticity steel. Materials Science \& Engineering A, 751. (2019) 340-350. doi.org/10.1016/j.msea.2019.02.057

[12] Speer J. G., Edmonds D. V., Rizzo F. C., Matlock D. K.: Partitioning of carbon from supersaturated plates of ferrite, with application to steel processing and fundamentals of the bainite transformation. Current Opinion in Solid State and Materials Science, 8/3-4. (2004) 219-237. https://doi.org/10.1016/j.cossms.2004.09.003

[13] Bachmaier A., Hausmann K., Krizan D., Pichler A.: Development of TBF steels with $980 \mathrm{MPa}$ tensile strength for automotive applications. In: Proceedings of Int. Conf. on New Developments in Advanced High Strength Steels. Colorado, June 2013.

[14] Singh H.: Nanosteel Intensive Body-in-White. Research Study. EDAG Inc. August 2013. 